\title{
Monitoring a commercial vineyard in New Zealand to maintain soil health and achieve long-term sustainability
}

\author{
Robert E White ${ }^{1}$ and Daniel Watson ${ }^{2}$ \\ ${ }^{1}$ Faculty of Veterinary and Agricultural Sciences, The University of Melbourne, Australia; email \\ robertew@unimelb.edu.au \\ ${ }^{2}$ National Vineyard Manager, Craggy Range Vineyards, Hawke's Bay, New Zealand; email \\ Daniel.Watson@craggyrange.com
}

\begin{abstract}
This paper illustrates the benefits of long-term monitoring of soil and vine health in Craggy Range's Te Muna vineyard in the Martinborough region of New Zealand. The soils at Te Muna are formed on two river terraces. The higher and older terrace, planted to Pinot Noir, is very gravelly; the lower and younger terrace, planted to Sauvignon Blanc, contains more silt and very fine sand. Both terraces are freely drained. Soil $\mathrm{pH}$, organic $\mathrm{C}$ and available $\mathrm{P}$ were monitored in selected blocks on both terraces. Under current management that includes cover crops and sheep grazing in winter, soil organic $\mathrm{C}$ has been stable for 10 years. Because of the regular application of RPR and intermittent liming, soil $\mathrm{pH}$ (water) has risen from c.5.5 to 6.5-7. Values for soil available P, measured by Olsen bicarbonate and Mehlich-3 extractions, diverged over time. The Olsen test indicated satisfactory P levels: conversely, the Mehlich test showed P values rising to very high levels, confirming Western Australian experience that this acid extraction is unsuitable for soils treated with RPR. Petiole and leaf blade P concentrations confirmed these results, but they showed greater interannual variation than the soil P measurements. Overall, the long-term sustainability of the vineyard should be assured.
\end{abstract}

\section{Introduction}

Craggy Range Vineyards has a reputation for distinctive wines of high quality, being named as 'New World Winery of the Year' in 2014. The company has a longterm commitment to maintaining healthy soils by continuous monitoring of key soil properties. This paper describes some of the practical issues that the vineyard manager must confront in monitoring the nutritional status of soil and vines to ensure the productive capacity of the vineyard and its long-term sustainability.

\section{Background information}

Craggy Range's Te Muna vineyard in the Martinborough region of the southern North Island, New Zealand, is used as a case study of the company's strategy. The annual rainfall is $783 \mathrm{~mm}$ with January-February being the driest months and June-July the wettest. The soils have formed on two river terraces. The higher and older terrace was laid down 50-60 000 years ago and is very gravelly; the lower younger terrace was laid down in Recent times and is also gravelly, but has more silt and very fine sand (Figure 1).

Of the two main varieties grown at Te Muna, Pinot Noir is planted on the upper terrace; Sauvignon Blanc mainly on the lower. Both varieties are on rootstocks. The soils on both terraces are freely drained except for some blocks on the lower terrace where there is an underlying clay layer. Drip irrigation, but no fertigation, is applied at the rate of 0.5 to $0.75 \mathrm{ML} / \mathrm{ha}$. Volunteer cover crops are grown in the mid-rows and sheep are grazed for four months in winter. There is a regular program of fertilizing with an $\mathrm{N}, \mathrm{P}, \mathrm{K}$ mix, supplemented with magnesite, ulexite, $\mathrm{S}$ prills, reactive phosphate rock (RPR) and potassium sulfate $\left(\mathrm{K}_{2} \mathrm{SO}_{4}\right)$, as deemed necessary from soil and plant testing. The RPR input varies from $100-150 \mathrm{~kg} / \mathrm{ha}, \mathrm{K}_{2} \mathrm{SO}_{4}$ from $50-100$ $\mathrm{kg} / \mathrm{ha}$ and $\mathrm{S}$ prills at $40 \mathrm{~kg} / \mathrm{ha}$. Lime is also applied infrequently to some blocks.

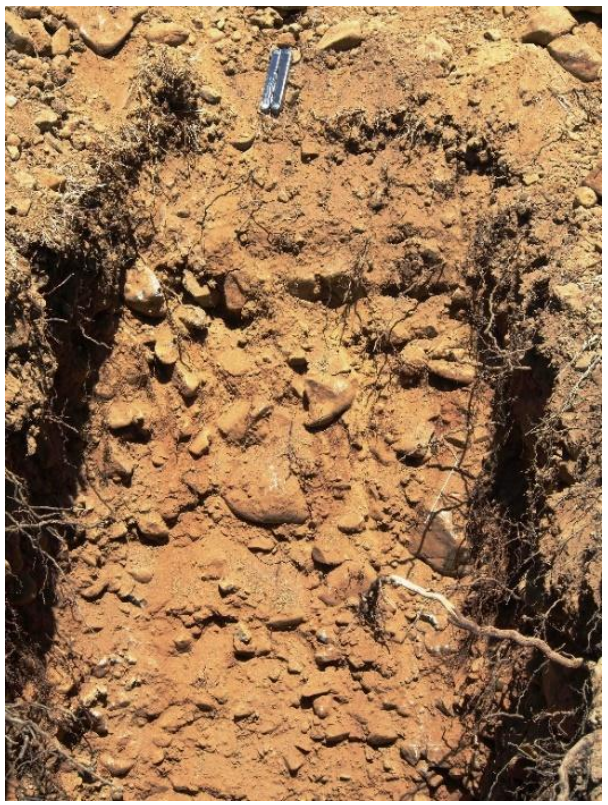

Figure 1 Soil profile on the lower terrace at Te Muna; the scale is $10 \mathrm{~cm}$ 


\subsection{Methods}

The vineyard of 93 ha has been divided into 40 blocks of varying size according to soil variation and vine performance. Since the early 2000 s, soil samples (0-15 $\mathrm{cm}$ ) have been taken from specific, under-vine locations in 'indicator' blocks that are representative of a zone, based on soil differences and vine performance. Each year, normally in June-July, 20 soil samples are taken with a $2.5 \mathrm{~cm}$ corer and bulked for each indicator block. The sampling locations are the same each year. The fine earth fraction $(<2 \mathrm{~mm})$ of all samples is analysed for soil $\mathrm{pH}$, organic carbon (C) and the macro- and micronutrients. Because the soils are so gravelly, this fraction comprises only $40-50 \%$ of the soil volume. Leaf petioles and blades are also sampled, usually at flowering but sometimes also at veraison.

The analyses are carried out by an internationally accredited laboratory in New Zealand. Soil $\mathrm{pH}$ is measured at a 1:2 soil:solution ratio in water, organic $\mathrm{C}$ by an NIR calibration of total $\mathrm{C}$ by Dumas combustion, and available phosphorus $(\mathrm{P})$ by Olsen bicarbonate [1] and Mehlich no. 3 [2] extractions. Plant analyses are done by ICP on acid digests of the dried, ground samples.

\section{Outcomes of the long-term monitoring}

\subsection{Soil organic carbon}

As shown in Figure 2, the long-term trend in soil organic carbon (SOC) is remarkably stable. The upper terrace soil, represented by Block 1 , is between 5 and $6 \% \mathrm{C}$; the lower terrace represented by Block 42 is about $3 \% \mathrm{C}$. Although the lower terrace soil has more silt and fine sand than the upper terrace soil, it is a younger soil and probably has not developed to its equilibrium $\mathrm{C}$ content yet. This difference was consistent for other blocks located in the upper and lower terraces. The vineyard management regime involving cover crops and sheep grazing for four months in winter has maintained SOC levels and this should benefit the structure of the topsoil.

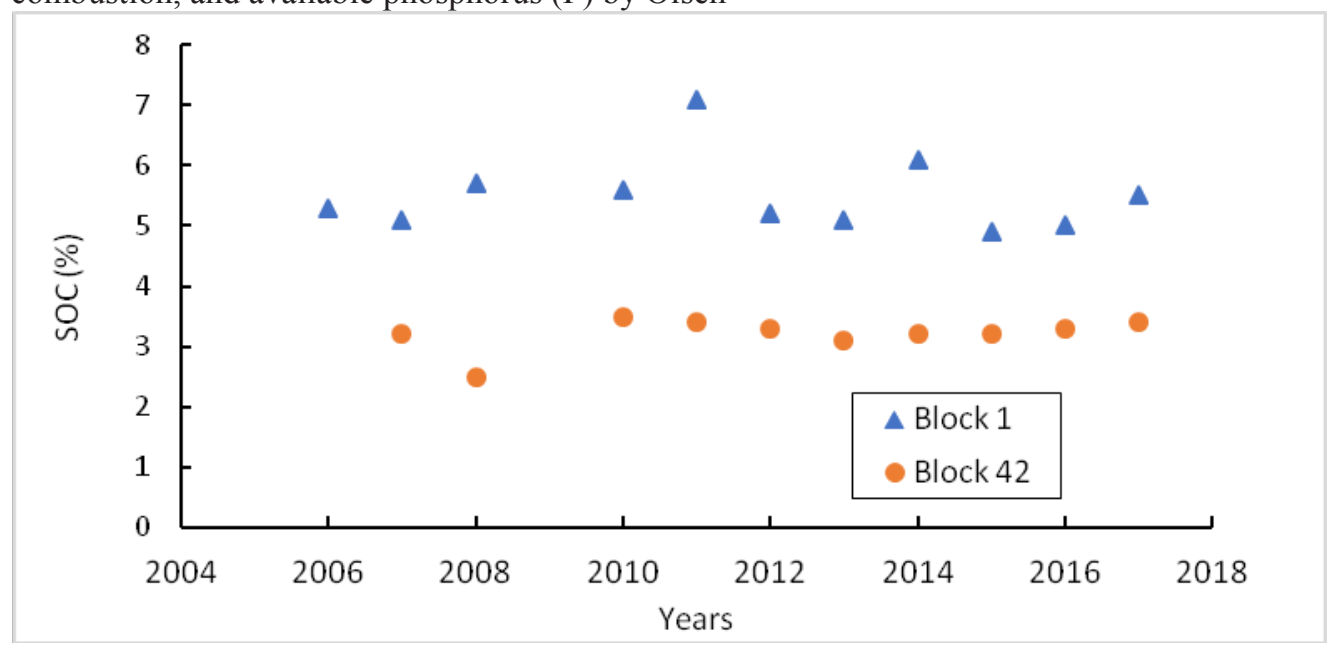

Figure 2 Long-term trend in SOC in the upper (Block 1) and lower terrace (Block 42) soils

\subsection{Soil pH}

The graphs in Figure 3, again for Blocks 1 and 42, show that soil $\mathrm{pH}$ has been increasing steadily over the monitoring period, approaching a value between 6.5 and 7. This trend is primarily the result of regular applications of RPR, which has a liming effect equivalent to about $40 \%$ of its equivalent weight in agricultural lime. Ideally, the soil $\mathrm{pH}$ (measured in water) should not be raised above 6.5-7 (corresponding to about 5.8-6.3 in 0.01 M $\mathrm{CaCl}_{2}$ ), otherwise soil micronutrients such as $\mathrm{Fe}$ and $\mathrm{Zn}$ may become less available.

\subsection{Available soil phosphorus}

The graphs in Figures 4 and 5 show the long-term trends in available soil $\mathrm{P}$ for Blocks 1 and 42, respectively, by both the Olsen and Mehlich tests. The trends are very similar for topsoil on the upper and lower terraces: Olsen values stay relatively constant, between 20 and $40 \mathrm{mg}$ $\mathrm{P} / \mathrm{kg}$ soil, over time. On the other hand, Mehlich values increase to high levels, up to $160 \mathrm{mg} \mathrm{P} / \mathrm{kg}$ in the case of Block 1 (upper terrace).
These trends are not unexpected when RPR has been used as a $\mathrm{P}$ fertilizer. First, previous research in New Zealand [3] has shown that the alkaline Olsen extraction did not adequately reflect the increase in $\mathrm{P}$ availability following RPR application to soils of varying P sorption capacity. Second, the Mehlich test, being an acid extraction, overestimates the $P$ availability of soils to which RPR has been applied. Extensive appraisal of trials in Western Australia [4] concluded that the Mehlich no. 3 test was not suitable for soils to which RPR had been applied. These authors gave a range of $<10$ (very low) to 40-70 (optimum) to $>70$ (high) to assess the results of the Mehlich test for soil $\mathrm{P}$ availability. Thus, the Mehlich results in Figures 4 and 5 apparently show very high available P levels. However, Olsen P values show little change over time and are mainly in the desired range of $15-40 \mathrm{mg} \mathrm{P} / \mathrm{kg}$, as identified by the New Zealand soil testing laboratory.

On a few occasions early in the monitoring period, subsoils were analysed for available P by the Olsen test. Table 1 gives examples. These figures show 
Table 1 A comparison of Olsen P values in the topsoils and subsoils at Te Muna

\begin{tabular}{llll} 
Year & Block & $\begin{array}{l}\text { Olsen P } \\
\text { topsoil } \\
(\mathrm{mg} / \mathrm{kg})\end{array}$ & $\begin{array}{l}\text { Olsen P } \\
\text { subsoil } \\
(\mathrm{mg} / \mathrm{kg})\end{array}$ \\
\hline 2006 & 1 & 49 & 22 \\
2006 & 1 & 35 & 22 \\
2012 & 42 & 39 & 26 \\
\hline 2006 & Mean for all & & 19 \\
& subsoils & & \\
\hline
\end{tabular}

that subsoil $\mathrm{P}$ values are $22-26 \mathrm{mg} \mathrm{P} / \mathrm{kg}$, with an average value for the whole vineyard of $19 \mathrm{mg} \mathrm{P} / \mathrm{kg}$. This appears to be adequate, except that these are values for the fine earth fraction, which comprises only about $50 \%$ of the soil volume.

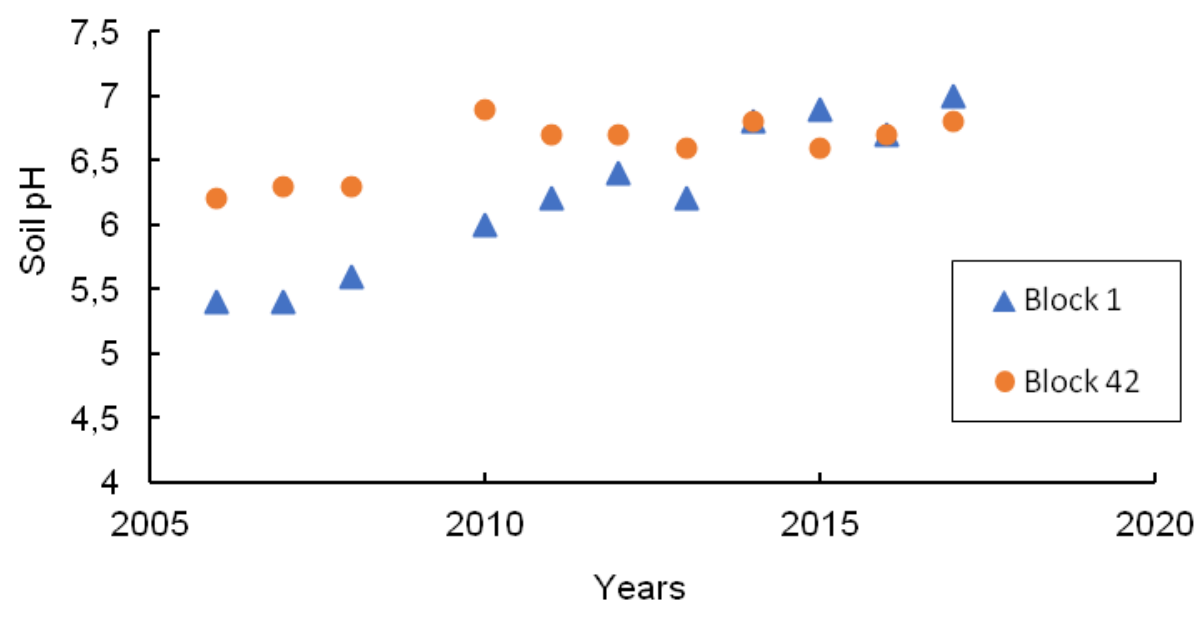

Figure 3 Long-term trend in soil pH (water) for the upper (Block 1) and lower terrace (Block 42) soils

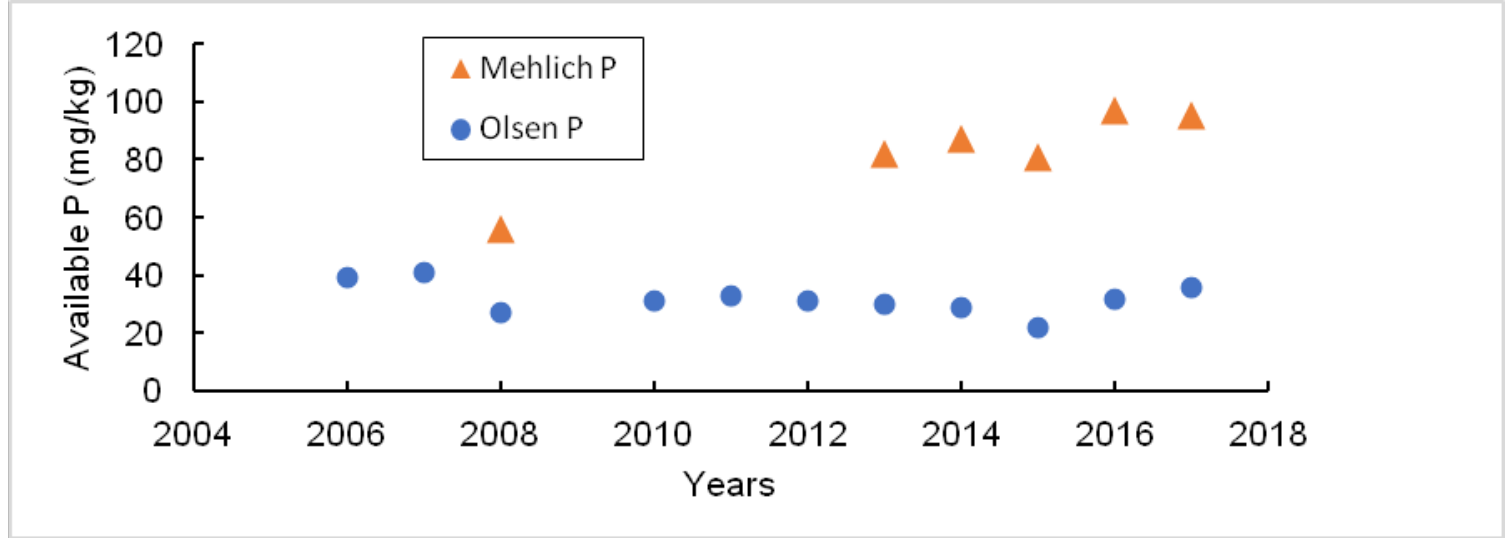

Figure 4 Long-term trend in available soil $\mathrm{P}$ in the upper terrace soil (Block 1)

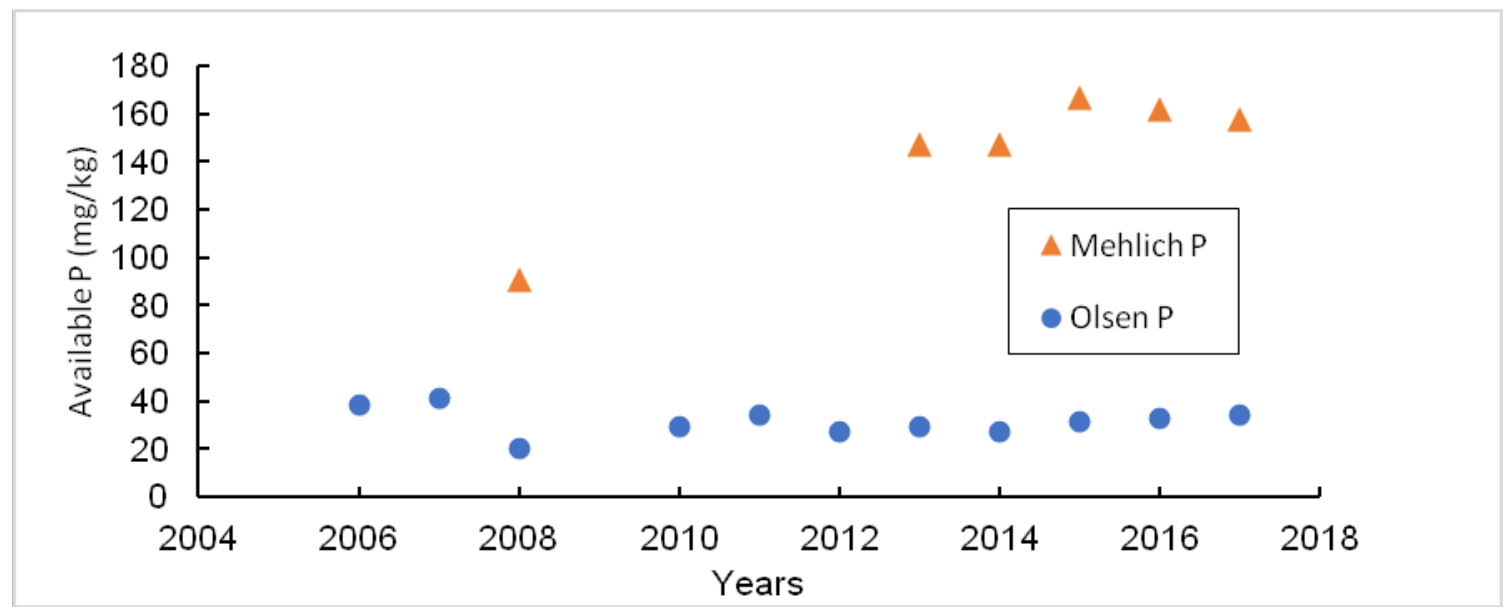

Figure 5 Long-term trend in available soil P in the lower terrace soil (Block 42 
Effectively, therefore, these subsoil values are equivalent to only $10-13 \mathrm{mg} \mathrm{P} / \mathrm{kg}$, which is deficient. Unfortunately, no data are available for subsoil Mehlich values.

Although topsoil Olsen P values should be similarly discounted for the presence of inert gravel, they still fall mainly in the desired range of $15-40 \mathrm{mg} \mathrm{P} / \mathrm{kg}$. Hence one concludes that the application of RPR and some soluble $\mathrm{P}$ fertilizer to these soils has maintained available $\mathrm{P}$ in the desired range. Even after discounting the high Mehlich P values for the presence of gravel, it appears that the Mehlich test is overestimating P availability.

\subsection{Plant analyses for $P$}

Given the uncertainties associated with the interpretation of the soil tests for available $\mathrm{P}$, plant analysis may give a more reliable indication of the $\mathrm{P}$ status of the vines. However, there are two problems with plant analysis for a mobile element such as P. First, concentrations can change rapidly with phenological development of the vine: for example, a decrease in concentration occurs from flowering through fruit set to veraison. The data in Table 2 illustrate this change for Sauvignon Blanc vines in Block 35 (lower terrace) from flowering to early veraison.

Table 2 A comparison of leaf blade and petiole $\mathrm{P}$ concentrations at flowering and veraison at Te Muna

\begin{tabular}{llll} 
Block & $\begin{array}{l}\text { Date of } \\
\text { sampling }\end{array}$ & $\begin{array}{l}\text { Leaf P } \\
(\%)\end{array}$ & $\begin{array}{l}\text { Petiole } \\
\text { P }(\%)\end{array}$ \\
\hline 35 & 25.11 .2008 & 0.55 & \\
27.01 .2009 & 0.29 & \\
& 24.11 .2006 & 0.35 & 0.57 \\
& 18.01 .2007 & 0.23 & 0.23
\end{tabular}

Second, the plant $\mathrm{P}$ concentration tends to be lower in vines under moisture stress, irrespective of the soil $\mathrm{P}$ status. Generally speaking, petiole values reflect the current $\mathrm{P}$ status of the vine better than blade values which reflect the accumulation of $\mathrm{P}$ in the vine up to the time of sampling.

Figures 6 and 7 show the trends in petiole and leaf $\mathrm{P}$ concentrations for Pinot Noir in Block 1 (upper terrace) and Sauvignon Blanc in Block 42 (lower terrace), sampled at flowering. Based on New Zealand experience, the desired ranges for petiole $\mathrm{P}$ and leaf $\mathrm{P}$ at flowering are $0.18-0.45 \%$ and $0.16-0.25 \%$, respectively. Figure 6 shows that leaf $\mathrm{P}$ is relatively stable over time and in the desired range, which is consistent with the Olsen soil $\mathrm{P}$ results (Figure 4). Petiole $\mathrm{P}$ is more variable over time, ranging from $0.1 \%$ to $0.36 \%$. The lower values in 2010 , 2011, 2012 and again in 2014 and may well reflect the later sampling times in these years.

Figure 7 (Sauvignon Blanc, Block 42) shows a generally consistent story with Figure 6 - petiole and leaf $\mathrm{P}$ concentrations are generally in the desired range, except for petiole $\mathrm{P}$ in 2010 and 2011 when the vines were sampled late. However, leaf $\mathrm{P}$ values were also low in 2010 and 2011 so that vine moisture stress could have affected $\mathrm{P}$ concentrations in those years. Apart from the interannual variability introduced by time of sampling and moisture stress, it is important to note that the plant analyses indicate the vines are in the desired $\mathrm{P}$ range, with a trend towards higher values over time in the Sauvignon Blanc in Block 42, a more vigorous site on the lower terrace.

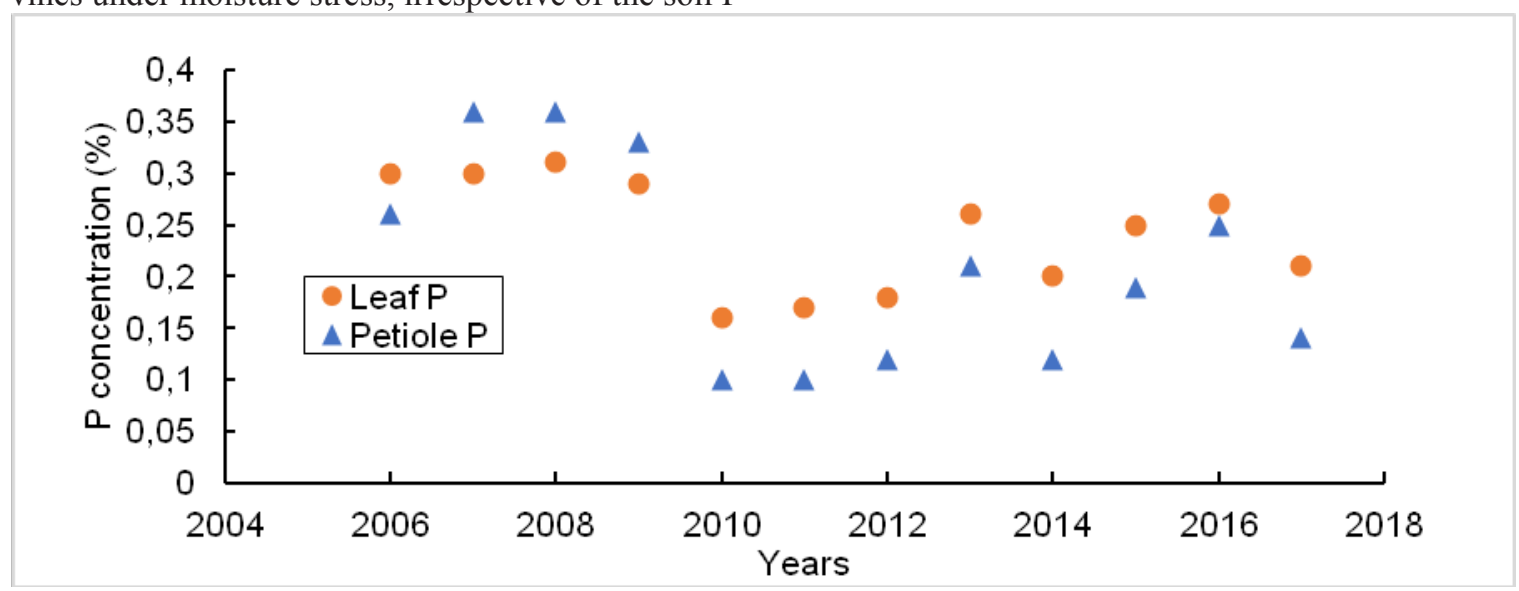

Figure 6 Trends in leaf blade and petiole P concentrations for Pinot Noir on the upper terrace (Block 1) 


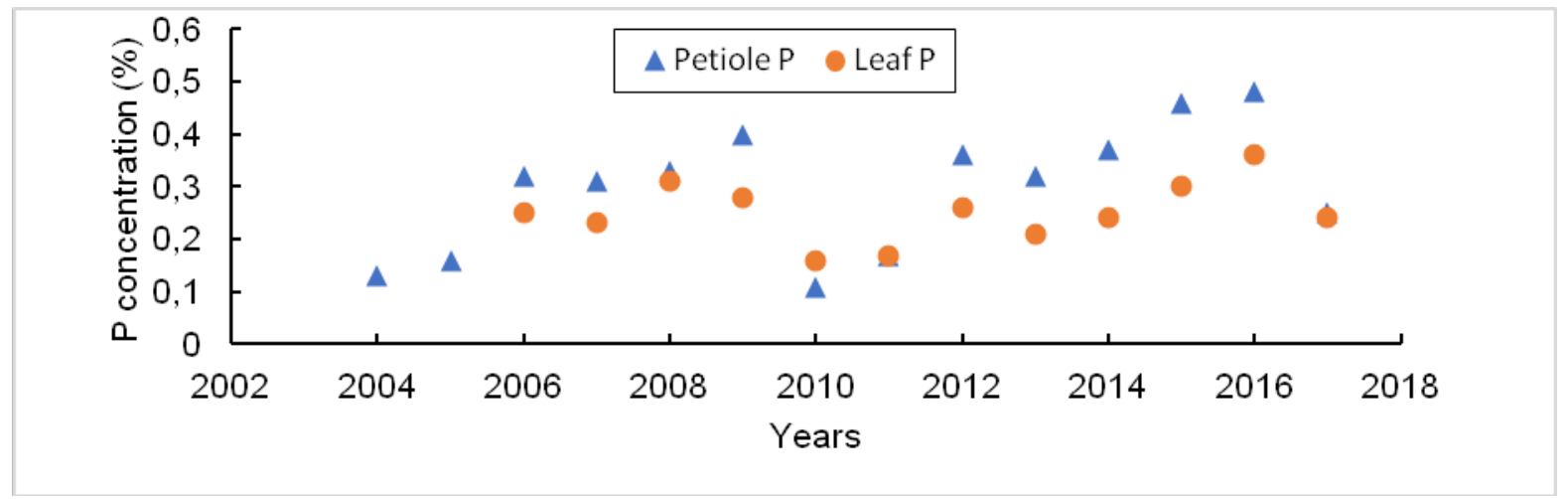

Figure 7 Trends in leaf blade and petiole P concentrations for Sauvignon Blanc on the lower terrace (Block 42)

\section{Conclusions}

The examples of soil and plant analysis given here are representative of soil conditions in the Te Muna vineyard since the early 2000s. Clearly the prevailing soil management system is maintaining or improving soil health. Soil organic $\mathrm{C}$ has remained constant at 5-6\% for the older upper terrace soil and around $3 \%$ for the younger lower terrace soil. Some nitrogen $(\mathrm{N})$ is infrequently supplied in an N:P:K mix, but the main source of $\mathrm{N}$ is from soil organic $\mathrm{N}$. For example, the C:N ratio of the soil organic matter in the topsoil is consistently in the range 10-12. The potentially available $\mathrm{N}$ from mineralization in the topsoil is between 60 and $120 \mathrm{~kg} \mathrm{~N} / \mathrm{ha}$, with the higher values generally occurring in the lower terrace soils.

Soil pHs have been increasing steadily into the 6.5-7 range through the use of occasional lime applications, but more consistently through the use of RPR. They are now at the level where the rate of RPR dissolution will be extremely slow. As the Mehlich soil P test shows, there is a substantial reserve of RPR residues in the topsoil so that future $\mathrm{P}$ fertilizer additions can be scaled back. For example, in $2017 \mathrm{P}$ inputs were reduced to $6.5-13 \mathrm{~kg} / \mathrm{ha}$, with higher values in this range being applied to the more gravelly, upper terrace soils.

Soil and plant analyses show that the P status of the soils is generally in the desired range. The use of RPR as a P fertilizer is justified on these freely drained, gravelly soils, because soluble P fertilizer can be leached. Furthermore, for a perennial plant such as the grapevine a slow-release source of $\mathrm{P}$ is satisfactory for the plant's needs and minimizes any impact of leached $\mathrm{P}$ on water quality in the nearby Huangarua River.

Overall, the management of the Te Muna vineyard is consistent with Craggy Range's commitment to the excellence and long-term sustainability of its wine business.

\section{Acknowledgements}

One of us (REW) gratefully acknowledges the opportunity to visit the Te Muna vineyard offered by Matt Stafford, Chief Winemaker, Craggy Range Pty Ltd.

\section{References}

1. S.R. Olsen, C.V. Cole, F.S. Watanabe, L.A. Dean, USDA Circular no. 939

2. A. Mehlich, Comm. Soil Sci. Plant Anal. 15, 1409 (1984)

3. S.R. Saggar, M.J. Hedley, R.E. White, Fert. Res. 33, 81 (1992)

4. K. Walton, D. Alle, in Supersoil 2004 (ed. B. Singh) Proc. $3^{\text {rd }}$ Australian New Zealand Soils Conference, Sydney, Australia, 5-9 Dec. (2004) 